Natalia KLEJDYSZ

Uniwersytet im. Adama Mickiewicza w Poznaniu

\title{
Kobiety w polskiej administracji publicznej
}

K iedy Irena Kosmowska została wiceministrem polityki społecznej K w Rządzie Ignacego Daszyńskiego, była pierwszą, i przez długie lata jedyną, kobietą w polskiej administracji rządowej. Uzyskanie przez Polki prawa wyborczego w 1918 roku nie oznaczało bowiem faktycznego dopuszczenia kobiet do gremiów rządowych w II Rzeczpospolitej. Fakt, iż kobiety dysponowały prawami politycznymi, paradoksalnie, przyczynił się do osłabienia działalności ruchów kobiecych w walce o równouprawnienie. Bierne i czynne prawa wyborcze uważano bowiem za uniwersalny sposób rozwiązujący problem dyskryminacji kobiet zarówno w sferze publicznej, jak i prywatnej. Dopiero pół wieku później na fali wielkiej kontestacji Nowej Lewicy wypłynęła ponownie kwestia kobieca. Jednak do krajów bloku wschodniego druga fala feminizmu nie zdołała dotrzeć. Aktywność i aspiracje kobiet starano się w Polsce skanalizować w Lidze Kobiet Polskich czy też Kołach Gospodyń Wiejskich, które nie odegrały istotnej roli w życiu społecznym, a tym bardziej w życiu politycznym PRL.

Brak obywatelskiej legitymacji dla władzy komunistycznej, podobnie jak przed stu laty, w okresie zaborów, wymuszał konieczność skoncentrowania społecznych wysiłków na odzyskaniu suwerenności. Kobiety, pozostając na marginesie walki z komunistycznym reżimem, po 1989 roku były praktycznie nieobecne w gremiach decyzyjnych, kreujących nową Polskę. Zarzewie buntu antykomunistycznego tkwiło bowiem środowisku robotniczym, skupiającym się w zakładach przemysłu ciężkiego (stocznie, fabryki samochodów, kopalnie), w których zatrudnienie kobiet było niewielkie. Wyjątek stanowił przemysł tkacki, a łódzkie robotnice aktywnie włączyły się do protestów lat 80 . XX w. Również, wspierające robotników w ich walce, środowisko intelektualistów opozycyjnych było zmaskulinizowane. Zatem w momencie kształtowania reguł nowego, demokratycznego porządku brakło kobiet, które odgrywałyby znaczącą rolę w procesach decyzyjnych. Znamienne są wyniki wyborów parlamentarnych. Wprawdzie nie władza ustawodawcza jest przedmiotem rozważań w niniejszym 
artykule, jednak to przecież obie izby parlamentu stanowiły nowe kanony prawa, w oparciu o które dokonywała się transformacja ustrojowa. Powracając jednak do rezultatów głosowania do Sejmu kontraktowego - do izby niższej weszły 62 kobiety, a do Senatu - 7, co stanowiło odpowiednio 13,5 oraz 7 proc. składu (Siemieńska, s. 28). W następnych, prawdziwie wolnych, wyborach parlamentarnych w 1991 roku udział kobiet był znacznie mniejszy. Partie wystawiły na swych listach znacznie mniejszą liczbę kandydatek, a do Sejmu dostało się jedynie 44 spośród nich, do Senatu - 8 (9,5 i 8\%). Przyczyn takiego wyniku można upatrywać we wzroście znaczenia i prestiżu Parlamentu. Zadziałał mechanizm przejmowania, polegający na aktywizacji mężczyzn w sferach cieszących się rzeczywistym prestiżem, autorytetem, a w końcu mających wpływ na zakres władzy.

Niski poziom samoorganizacji kobiet nie pozwolił na natychmiastową reakcję i wzięcie udziału w walce o władzę. Nie sprzyjał (i nadal nie sprzyja) temu specyficzny model kobiety Polki, zdeterminowany tradycją katolicką i skomplikowaną historią, sytuującą kobietę w mało interesującym kontekście: matki, westalki ogniska domowego, sanitariuszki, pielęgniarki, opiekunki-karmicielki. Niemożność wyrwania się spod wpływów tego stereotypu, tym trwalszego, że mającego fundamenty religijne, ograniczał i ogranicza polityczną aktywność kobiet. Problem dotyczył (i dotyczy nadal) nie tylko męskiego postrzegania, ale również samooceny kobiet.

Zmianie takiego stanu rzeczy niewątpliwie sprzyjają rozwiązania kwotowe wprowadzone do ordynacji wyborczej. Jednak, jak pokazały wyniki ostatnich wyborów parlamentarnych, parytet nie rozwiązuje problemu niskiej reprezentatywności kobiet w organach, zarówno stanowiących, jak i rządzących. Fakt, iż, mimo (a może - dzięki) 35-procentowej kwocie płci na listach wyborczych, kobiet w ławach poselskich jest tylko o 3\% więcej kobiet niż w Sejmie VI kadencji, świadczy o konieczności przyłączenia się Polski do ogólnoeuropejskich działań systemowych. Służy temu polityka gender mainstreaming. Jest to bowiem strategia włączenia problemów i doświadczeń płci (zarówno kobiet, jak i mężczyzn), polegająca na planowaniu, wdrażaniu, monitorowaniu i ocenie polityk i programów we wszystkich dziedzinach życia politycznego, ekonomicznego i społecznego tak, aby kobiety i mężczyźni odnosili równe korzyści, a nierówność się nie utrwalała (Gender Mainstreaming, 1997, IA). Strategia ta została opracowana w pierwotnej formie na V Światowej Konferencji w sprawie Kobiet ONZ w Pekinie w 1995 r. Dwa lata później jej 
założenia zostały zawarte w Traktacie amsterdamskim, stając się tym samym obowiązującymi dla wszystkich państw członkowskich Unii Europejskiej. Polska zatem, również jest zobowiązana do wdrażania postanowień Traktatu. Uszczegółowieniem strategii gender mainstreaming w UE są tzw. road maps - pięcioletnie programy wdrażania założeń tej strategii.

Gender mainstreaming zakłada więc działania długofalowe i wielopłaszczyznowe. Zmiany $\mathrm{w}$ obowiązującym prawie są jednym $\mathrm{z}$ elementów składowych, któremu musi towarzyszyć edukacja równościowa, pozwalająca na wyzwolenie się spod wpływów stereotypów płci. O tym, jakie są konsekwencje braku całościowego potraktowania problemu świadczą właśnie wyniki ostatnich wyborów parlamentarnych w Polsce. Mimo wprowadzenia kwot do ordynacji wyborczej, brak systemu suwakowego w połączeniu z wciąż stereotypowym sposobem postrzegania potrzeb i możliwości kobiet przyniósł o wiele gorszy, z punktu widzenia kobiet, od spodziewanego wynik głosowania.

W sferze administracji publicznej strategia gender mainstriming winna być wdrażana dwutorowo: w sferze zatrudnienia oraz w sferze decyzji. Chodzi jednak nie tylko o liczbę kobiet zatrudnionych w organach i instytucjach administracji publicznej, lecz o stanowiska, które zajmują. Autentyczna partycypacja kobiet w procesie decyzyjnym zwiększa poziom reprezentatywności rozstrzygnięć wykonawczych. Kobiety stanowią ponad połowę mieszkańców Polski, jednak ich rzeczywisty wpływ na sferę polityczną i ekonomiczną jest wciąż nieadekwatny.

Problem z oceną rzeczywistego udziału kobiet $\mathrm{w}$ organach administracji publicznej na poziomie centralnym wynika z jej specyfiki organizacyjnej. Tradycyjnie bowiem na tym szczeblu łączą się funkcje polityczne $\mathrm{z}$ administracyjnymi. Zatem rozważania na temat udziału kobiet $\mathrm{w}$ administracji publicznej muszą dotyczyć obu płaszczyzn.

Naczelnym organem politycznym w administracji centralnej jest minister. Pierwszą po 1989 roku kobietą pełniącą tę funkcję była Izabela Cywińska - minister kultury i sztuki w rządzie Tadeusza Mazowieckiego. Była ona jednocześnie jedyną kobietą w gabinecie. Natomiast jedyną kobietą ministrem w rządzie Jana Krzysztofa Bieleckiego była Henryka Bochniarz, stojąca na czele resortu przemysłu i handlu. Barbara Blida była jedyną kobietą w rządach: Waldemara Pawlaka, Józefa Oleksego i Włodzimierza Cimoszewicza. Podlegało jej ministerstwo gospodarki przestrzennej i budownictwa. Zaskakujący może być fakt, że jedynym rządem, w którego składzie nie znalazła się żadna kobieta był gabinet Hanny Su- 
chockiej - jedynej premier w historii Polski. Najwięcej kobiet zasiadało w ławach rządowych za czasów premiera Jarosława Kaczyńskiego: Anna Fotyga, Grażyna Gęsicka, Elżbieta Jakubiak, Anna Kalata, Joanna Kluzik-Rostkowska ${ }^{1}$.

Najczęściej powierzanym kobietom resortem jest ministerstwo zajmujące się polityką społeczną ${ }^{2}$. Po 1989 roku kobiety stały na jego czele czterokrotnie $^{3}$. Dwukrotnie pełniły urząd ministra kultury i sztuki ${ }^{4}$, ministra sprawiedliwości ${ }^{5}$, finansów ${ }^{6}$, edukacji narodowej, sportu ${ }^{7}$ oraz rozwoju regionalnego ${ }^{8}$.

Obecnie wśród osiemnastu ministrów resortowych, cztery - to kobiety: Elżbieta Bieńkowska - minister rozwoju regionalnego; Barbara $\mathrm{Ku}$ drycka - minister nauki i szkolnictwa wyższego; Joanna Mucha-minister sportu i turystyki; Krystyna Szumilas - minister edukacji narodowej. A zatem o jedną mniej niż przed wyborami parlamentarnymi 2011 roku. Na dotychczasowym stanowisku pozostały: E. Bieńkowska i B. Kudrycka. Również na czele resortu edukacji narodowej oraz pracy i polityki społecznej zasiadły kobiety ${ }^{9}$. Jednak ministerstwo zdrowia powierzono Bartoszowi Arłukowiczowi.

Wśród sekretarzy stanu w ministerstwach zdecydowanie przeważają mężczyźni. Siedemnastu mężczyzn i tylko dwie kobiety - sprawują to sta-

1 J. Kluzik-Rostkowska zastapiła na stanowisku ministra pracy i polityki społecznej Annę Kalatę. Zatem w rządzie J. Kaczyńskiego piastowało urząd ministra w jednym czasie pięć kobiet.

2 Ministerstwo to zmieniało swoją nazwę: ministerstwo polityki społecznej; ministerstwo pracy i polityki społecznej.

3 I. Jaruga-Nowacka, A. Kalata, J. Kluzik-Rostkowska, Jolanta Fedak.

4 I. Cywińska, J. Wnuk-Nazarowa.

5 H. Suchocka, B. Piwnik.

${ }^{6}$ H. Wasilewska-Trenkner, Z. Gilowska, której urząd ten powierzono dwukrotnie - za rządów premiera K. Marcinkiewicza oraz J. Kaczyńskiego.

7 W okresie rządów L. Millera K. Łybacka pełniła urząd ministra edukacji narodowej i sportu. Podział ministerstwa na dwa resorty: edukacji narodowej oraz sportu i turystyki nastąpił w roku 2005. W rządzie J. Kaczyńskiego drugim resortem kierowała E. Jakubiak, a w rządzie D. Tuska MEN powierzono K. Hall, a obecnie urząd ten pełni K. Szumilas.

${ }^{8}$ G. Gęsicka (premier K. Marcinkiewicz), dwukrotnie E. Bieńkowska (premier D. Tusk).

9 W listopadzie 2011 Jolantę Fedan na stanowisku ministra pracy i polityki społecznej zastąpił Władysław Kosiniak-Kamysz. 
nowisko (przy jednym wakacie). W randze podsekretarza stanu na 80 stanowisk, jedynie 22 zajmują kobiety.

Odmiennie kształtuje się sytuacja kadrowa w gabinetach politycznych poszczególnych ministrów. Funkcję dyrektora gabinetu pełni bowiem dziewięć kobiet i sześciu mężczyzn (w tym jeden jako p.o.) ${ }^{10}$.

Tabela 1

Udzial kobiet na stanowiskach politycznych poszczególnych ministerstw

\begin{tabular}{|c|c|c|c|c|c|c|c|c|}
\hline \multirow{2}{*}{ Ministerstwo } & \multicolumn{2}{|c|}{$\begin{array}{l}\text { Sekretarz } \\
\text { stanu }\end{array}$} & \multicolumn{2}{|c|}{$\begin{array}{c}\text { Podsekretarz } \\
\text { stanu }\end{array}$} & \multicolumn{2}{|c|}{$\begin{array}{l}\text { Dyrektor } \\
\text { generalny }\end{array}$} & \multicolumn{2}{|c|}{$\begin{array}{l}\text { Dyrektor ga- } \\
\text { binetu polit. }\end{array}$} \\
\hline & $\mathbf{K}$ & $\mathbf{M}$ & $\mathbf{K}$ & $\mathbf{M}$ & $\mathbf{K}$ & $\mathbf{M}$ & $\mathbf{K}$ & $\mathbf{M}$ \\
\hline Administracji i cyfryzacji & & 1 & 2 & 2 & 1 & & 1 & \\
\hline Edukacji Narodowej & & 1 & 1 & 2 & & 1 & 1 & \\
\hline Finansów & 1 & & 1 & 6 & 1 & & & 1 \\
\hline Gospodarki & & 2 & 3 & 3 & $1(\mathrm{z})$ & & 1 & \\
\hline $\begin{array}{l}\text { Kultury i Dziedzictwa Narodo- } \\
\text { wego }\end{array}$ & & 1 & 2 & & $\mathrm{~V}$ & $\mathrm{~V}$ & $\mathrm{~V}$ & $\mathrm{~V}$ \\
\hline Nauki i Szkolnictwa Wyższego & & 1 & 1 & 2 & & 1 & & 1 (p.o.) \\
\hline Obrony Narodowej & & 1 & 1 & 2 & $\mathrm{~V}$ & $\mathrm{~V}$ & 1 & \\
\hline Pracy i Polityki Społecznej & & 2 & 1 & 2 & 1 & & 1 & \\
\hline Rolnictwa i Rozwoju Wsi & & 1 & & 2 & & 1 & 1 & \\
\hline Rozwoju Regionalnego & 1 & & 1 & 3 & & 1 & $\mathrm{~V}$ & $\mathrm{~V}$ \\
\hline Skarbu & & 1 & & 4 & & 1 & $\mathrm{~V}$ & $\mathrm{~V}$ \\
\hline Sportu i Turystyki & & 1 & 1 & 1 & $1(\mathrm{z})$ & & 1 & \\
\hline Spraw Wewnętrznych & & 1 & & 3 & & 1 & 1 & \\
\hline Spraw Zagranicznych & & 1 & 3 & 2 & & 1 & & 1 \\
\hline Sprawiedliwości & & 1 & & 4 & $1(\mathrm{z})$ & & & 1 \\
\hline Środowiska & & 1 & 2 & 2 & & 1 & & 1 \\
\hline $\begin{array}{l}\text { Transportu, Budownictwa i Gos- } \\
\text { podarki Morskiej }\end{array}$ & & 1 & 2 & 4 & & 1 & 1 & \\
\hline Zdrowia & 1 & & 1 & 3 & $\mathrm{~V}$ & $\mathrm{~V}$ & & 1 \\
\hline
\end{tabular}

Źródło: Opracowanie własne na podstawie danych zamieszczonych na stronach internetowych poszczególnych ministerstw.

${ }^{10} \mathrm{~W}$ trzech przypadkach na stanowisku dyrektora gabinetu politycznego są wakaty: Ministerstwo Kultury i Dziedzictwa Narodowego, Ministerstwo Rozwoju Regionalnego oraz Ministerstwo Skarbu. 
W terenowych organach rządowych stanowiska polityczne powierzono przede wszystkim mężczyznom. Na szesnastu wojewodów tylko pięć to kobiety ${ }^{11}$.

Tabela 2

Kobiety wojewodowie- stan obecny

\begin{tabular}{||l|c|c|}
\hline \multicolumn{1}{|c|}{ Województwo } & K & M \\
\hline Dolnośląskie & & X \\
\hline Kujawsko-pomorskie & $\mathrm{X}$ & \\
\hline Lubelskie & $\mathrm{X}$ & \\
\hline Lubuskie & & $\mathrm{X}$ \\
\hline Łódzkie & $\mathrm{X}$ & \\
\hline Małopolskie & & $\mathrm{X}$ \\
\hline Mazowieckie & & $\mathrm{X}$ \\
\hline Opolskie & $\mathrm{X}$ & \\
\hline Podkarpackie & & $\mathrm{X}$ \\
\hline Podlaskie & & $\mathrm{X}$ \\
\hline Pomorskie & & $\mathrm{X}$ \\
\hline Śląskie & $\mathrm{X}$ & \\
\hline Świętokrzyskie & & $\mathrm{X}$ \\
\hline Warmińsko-mazurskie & & $\mathrm{X}$ \\
\hline Wielkopolskie & & $\mathrm{X}$ \\
\hline Zachodniopomorskie & & \\
\hline
\end{tabular}

Źródło: Opracowanie własne na podstawie danych zamieszczonych na stronach internetowych Rady Ministrów.

Pierwszą kobietą wojewodą po 1989 roku była Krystyna Łukaszuk (województwo podlaskie) $^{12}$. W 1999 roku została mianowana przez premiera Jerzego Buzka. Pełniła tę funkcję do kolejnych wyborów parlamentarnych. Jako członkini Akcji Wyborczej Solidarność, po przejęciu władzy przez lewicę, utraciła swoje stanowisko.

Mimo że Sojusz Lewicy Demokratycznej był i jest postrzegany jako jeden z największych orędowników równouprawnienia kobiet, to okres

11 W województwach: kujawsko-pomorskim, lubelskim, łódzkim, podkarpackim i świętokrzyskim.

12 Pierwsza wojewodą w Polsce powojennej była Zofia Grzebisz-Nowicka (województwo siedleckie). Pełniła tę funkcję w latach 1976-1979. 
rządów SLD charakteryzuje się bardzo niskim (jeśli nie żadnym) udziałem kobiet w organach terenowej administracji rządowej. Dopiero w 2003 roku wojewodą opolską została Elżbieta Rutkowska (SLD), która urząd ten pełniła do wyborów parlamentarnych w 2005 roku.

Rządy prawicowej koalicji PiS, Samoobrona, LPR nie przyniosły na tej płaszczyźnie zasadniczych zmian. W szesnastu województwach znalazło się miejsce tylko dla dwóch kobiet wojewodów: Ewy Kraus (PiS), która pełniła ten urząd przez dwa lata, do listopada 2007 roku oraz Anny Szyszki (PiS), która była wojewodą jedynie przez siedem miesięcy.

Dopiero kolejne wybory parlamentarne i zwycięstwo Platformy Obywatelskiej przyniosły pewną zmianę ilościową. Urząd wojewody powierzono czterem kobietom: Genowefie Tokarskiej (PSL) w województwie lubelskim, Helenie Hatce (PO) w Lubuskiem, Jolancie Chełmińskiej (PO) w Łódzkiem, Bożentynie Pałce-Korubie (PO) w Świętokrzyskiem.

Wykres 1. Udzial kobiet w sprawowaniu urzędu wojewody od 1999 roku

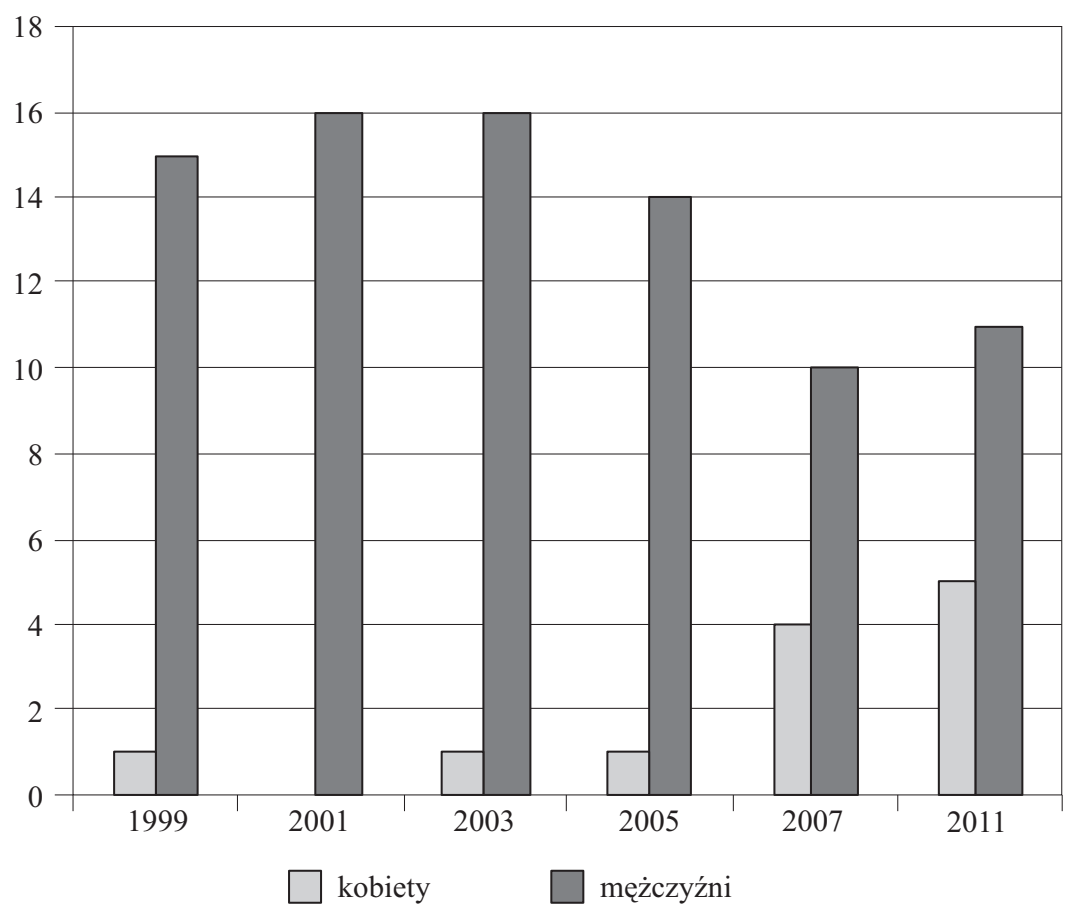

Źródło: Opracowanie własne na podstawie danych dostępnych na stronach internetowych Rady Ministrów. 
Ponieważ wybory parlamentarne w 2011 roku przyniosły ponownie wygraną PO, zmian personalnych w województwach było niewiele. Już rok wcześniej Ewa Mes (PSL) zastąpiła na urzędzie wojewody kujawsko-pomorskiego Rafała Bruskiego, a Małgorzata Chomycz (PO) Mirosława Karapyta (PSL) i do dziś obie pełnią powierzone stanowiska. W grudniu 2011 roku wojewodą lubelską została Jolanta Szołno-Koguc (PO) (zastąpiła G. Tokarską). Nadal, od 2007 roku, urząd wojewody pełnią B. Pałka-Koruba oraz J. Chełmińska. Obecnie więc w pięciu województwach administracja rządowa w terenie spoczywa w rękach kobiet.

Wśród pracowników administracji rządowej na stanowiskach stricte administracyjnych przeważają kobiety. Według Anny Borowskiej, radcy Prezesa Rady Ministrów, w 2009 roku korpus Służby Cywilnej liczył 123 tys. osób. Kobiety stanowiły 69\% zatrudnionych. Były zatrudnione przede wszystkim w administracji skarbowej, urzędach wojewódzkich i administracji niezespolonej. Na stanowiskach wyższych urzędników, a więc decyzyjnych lub takich, w ramach których przygotowywane są podstawy merytoryczne decyzji, połowa to kobiety (Kobiety w stużbie publicznej, 2011). Jednak urzędy wyższe są obsadzane najczęściej poprzez konkursy. Wśród dyrektorów generalnych osiemnastu ministerstw jest sześć kobiet ${ }^{13}$ i dziewięciu mężczyzn, przy trzech wakatach. Jeśli jednak przyjrzymy się poszczególnym departamentom ministerstw ta względna równowaga zostaje zachwiana. Jako przykład przywołajmy ministerstwo transportu, budownictwa i gospodarki morskiej. W ramach tego ministerstwa działa 14 departamentów. Wśród 12 dyrektorów (przy dwóch wakatach) 5 to kobiety. W przypadku zastępców dyrektorów departamentów powraca względna równowaga: na 28 stanowisk - 13 zajmują kobiety.

Tabela 3

Dyrektorzy i zastępcy dyrektorów departamentów Ministerstwa Transportu, Budownictwa i Gospodarki Morskiej - podzial wg płci

\begin{tabular}{||c|c|c|c|c||}
\hline \multirow{2}{*}{ Departament } & \multicolumn{2}{|c|}{ Dyrektor } & \multicolumn{2}{c||}{ Zastępca } \\
\cline { 2 - 5 } & K & M & K & M \\
\hline \multirow{2}{*}{1} & 2 & 3 & 4 & 5 \\
\hline GN & 1 & & & 2 \\
\hline DGPiB & $\mathrm{x}$ & $\mathrm{X}$ & 1 & 1 \\
\hline
\end{tabular}

13 Dwie na stanowisku zastępcy. 


\begin{tabular}{|l|c|c|c|c||}
\hline \multicolumn{1}{|c|}{1} & 2 & 3 & 4 & 5 \\
\hline DM & & 1 & 1 & 1 \\
\hline DO I & & 1 & 1 & 2 \\
\hline DO II & $\mathrm{x}$ & $\mathrm{X}$ & & 1 \\
\hline DTM i BŻ & 1 & & 2 & \\
\hline DD i A & & 1 & 2 & \\
\hline DL & & 1 & $\mathrm{X}$ & $\mathrm{x}$ \\
\hline DTD & & 1 & & 2 \\
\hline DTK & & 1 & & 2 \\
\hline DF UE & 1 & 1 & 3 & 1 \\
\hline DB & 1 & & 1 & 1 \\
\hline DK & 1 & & 2 & 1 \\
\hline DP & & & \\
\hline
\end{tabular}

Źródło: Opracowanie własne na podstawie danych zamieszczonych na stronie internetowej MTBiGM.

Inny przykład to Ministerstwo Spraw Zagranicznych, resort, jak twierdzi A. Fabryczewska-Chojnicka, uznawany za znacznie sfeminizowany. Na 1600 pracowników ministerstwa ponad 50\% stanowią kobiety. Jednak na stanowiskach kierowniczych - tylko 30\% (Kobiety w stużbie publicznej, 2011).

Niezadowalający poziom zatrudnienia kobiet w administracji publicznej, zwłaszcza na stanowiskach decyzyjnych, jest również dostrzegany przez opinię społeczną. Podczas badań Centrum Badania Opinii Społecznej blisko połowa respondentów (47\%) uznała, że w rządzie jest za mało kobiet, a tylko $8 \%$ twierdziło, że udział kobiet w tej sferze jest zbyt wysoki. W porównaniu z wynikami badań przeprowadzonych dwadzieścia jeden lat temu zwolenników zwiększenia partycypacji kobiet jest o 6\% więcej, a przeciwników o 7\% mniej.

Znacznie, w porównaniu z rokiem 1992, wzrosła liczba osób uważających, że za mało kobiet pracuje w administracji państwowej. Dziś (w 2013 roku) twierdzi tak 42\% ankietowanych, a więc o 12\% więcej niż podczas pierwszego badania przeprowadzonego przez CBOS (Kobiety $w \dot{z} y c i u$ publicznym, 2013).

Również na odpowiedzi ankietowanych poważny wpływ ma własna płeć. Respondentki znacznie częściej wyrażają przekonanie, że kobiet jest zbyt mało na stanowiskach kierowniczych w analizowanych obszarach, natomiast mężczyźni są zwolennikami utrzymania status quo. 
Czy, Pana(i) zdaniem, więcej, tyle samo czy też mniej kobiet niż obecnie powinno zajmować kierownicze stanowiska

\begin{tabular}{|l|c|c|c|c|}
\hline \multirow{2}{*}{} & \multicolumn{2}{|c|}{ W rządzie } & \multicolumn{2}{c|}{ W administracji państwowej } \\
\cline { 2 - 5 } & więcej & mniej & więcej & mniej \\
\hline Kobiety & 57 & 6 & 51 & 4 \\
\hline Mężczyźni & 37 & 10 & 31 & 8 \\
\hline
\end{tabular}

Źródło: Kobiety w życiu publicznym, komunikat z badań Centrum Badania Opinii Społecznej, marzec 2013, BS/34/2013.

Opierając się na badaniach CBOS można stwierdzić, że nastapiła zmiana w postrzeganiu przyczyn mniejszego udziału kobiet w życiu publicznym. Wprawdzie nadal większość respondentów uważa, że wynika to ze znacznego zaangażowania kobiet w wykonywanie obowiązków domowych, ale w porównaniu z rokiem 1997 liczba zwolenników takiej opinii znacznie zmniejszyła się (z 71 do 59\%), podobnie jak tych, którzy uważaja, że przyczyną omawianego zjawiska jest brak zainteresowania wśród kobiet pracą w sferze publicznej czy też ich niewystarczające kompetencje. Znacznie wzrosła natomiast liczba osób przekonanych, że źródłem problemu jest dominacja mężczyzn w życiu publicznym (z 36 do $43 \%$ ). Przy czym opinię taką wyrażają przede wszystkim kobiety, a biorąc pod uwagę poziom wykształcenia - osoby z wykształceniem wyższym. Można domniemywać, że jest to efekt aktywizacji środowisk feministycznych i świadectwo, że argumentacja przez nie stosowana spotyka się coraz częściej z pozytywnym odbiorem.

Konkludując, należy zauważyć tendencję feminizacji administracji publicznej. Kobiety chętnie podejmują zatrudnienie w tym sektorze, ale prawdopodobnie wynika to nie tyle $\mathrm{z}$ przekonania o większym wpływie na procesy decyzyjne urzędników tego sektora, lecz z przeświadczenia o większej stabilności pracy w administracji publicznej niż w sektorze prywatnym. Większość kobiet znajdujących zatrudnienie w administracji publicznej to osoby dobrze wykształcone. W 2010 roku 54 procent urzędniczek miało wykształcenie wyższe. W porównaniu z rokiem 2004 było ich o $18 \%$ więcej (Rybiński).

Jednak, mimo wysokich kwalifikacji kobiet zatrudnionych w administracji publicznej, dostrzegalne są przejawy segregacji pionowej ze względu na płeć. Oznacza to, iż kobiety mają niewielki rzeczywisty udział 
w procesach decyzyjnych, który wynika z dysproporcji w reprezentacji kobiet na stanowiskach kierowniczych w administracji. Zjawisko to nie tylko nie zanika, ale utrwala się z powodu niskiego poziomu ,świadomości i wiedzy na temat zasady równego traktowania w zatrudnieniu w administracji publicznej" (Branka, Rawłuszko i Siekiera, 2010, s. 4). Zmianom nie sprzyja zapewne brak instrumentów, które promowałyby udział kobiet na stanowiskach decyzyjnych. Dotyczy to instytucji i organów wszystkich szczebli: centralnego, regionalnego i lokalnego.

Brakuje również oferty edukacyjnej i szkoleniowej w zakresie równości płci adresowanej do administracji publicznej. Kategoria i perspektywa płci nie jest również uwzględniana ani w badaniach, analizach i diagnozach opracowywanych z myślą o sektorze publicznym ani w formułowaniu polityk i działań (Branka, Rawłuszko i Siekiera, 2010).

Widocznym skutkiem takiej polityki jest z jednej strony feminizacja administracji publicznej, a z drugiej - ograniczenie dostępu kobiet do stanowisk decyzyjnych.

Skutecznym rozwiązaniem problemu, wzmacniającym legitymizację władzy, byłoby zapewne wprowadzenie strategii gender mainstreaming. Edukacja w kierunku nowoczesnego spojrzenia na kwestię ochrony osób nierówno traktowanych już na poziomie szkół i wyższych uczelni przynosi efektywne zmiany w innych krajach europejskich.

Jak twierdzi E. Lisowska, pojawiające się propozycje zastosowania reguły parytetu płci w odniesieniu do ministrów (Kobiety w stużbie publicznej) są raczej nierealne i nie są poważnie brane pod uwagę w dyskursie publicznym. Jeśli jednak kobiety stanowią ponad połowę obywateli kraju, to ich proporcjonalny udział w rządzeniu byłby pełnym usankcjonowaniem reguł demokratycznego systemu politycznego.

\section{Bibliografia}

Branka M., Rawłuszko M., Siekiera A. (2010), Zasada równości szans kobiet i mężczyzn w projektach Programu Operacyjnego Kapital Ludzki, Ministerstwo Rozwoju Regionalnego, Departament Zarządzania Europejskim Funduszem Społecznym, Warszawa.

Kobiety w życiu publicznym, Centrum Badania Opinii Społecznej, marzec 2013, $\mathrm{BS} / 34 / 2013$.

Gender Mainstreaming. Extract from Report of Economic and Social Council for 1997 (A/52/3, 18 September 1997). 
Kobiety w stużbie publicznej-szklany sufit? (2011), Krajowa Szkoła Administracji publicznej, 18.03.

Rybiński K. (2012), Magistra na urzędzie cienko przędzie, „Rzeczpospolita”, 23 marca, wyd. internetowe.

Siemieńska R. (1994), Wybierane i glosujqce. Kobiety w wyborach parlamentarnych III Rzeczpospolitej. Kobiety: dawne i nowe role, „Biuletyn Centrum Europejskiego Uniwersytetu Warszawskiego i Ośrodka Informacji i Dokumentacji Rady Europy", nr 1, s. 27-44.

\title{
Women in organs of state administration in Poland
}

\begin{abstract}
Summary
The amendments made to the electoral law, and effective as of 2011, introduced a quota system but they did not solve the problem of women's participation in public life. Each sex was guaranteed a minimum of $35 \%$ of seats on electoral lists, without the requirement of alternating the candidates of different sexes, allowing certain political parties to only appear to implement the legislation. Despite the legal regulation imposing a requirement to increase the number of female candidates on electoral lists, the number of women currently in parliament increased only marginally, which raises the question of the degree of women's participation in those executive organs of the state which are not required to observe a quota. There is much to be desired as regards the participation of women in the organs of state administration at both central and local levels in Poland. Political posts are clearly dominated by men. As regards administrative positions, the proportion of women depends on the degree of power connected with them: the higher the level in the hierarchy, the fewer women there are. As concerns 'executive' posts, we can talk not only about a balance of sexes, but even about the prevalence of women, in some cases. Therefore, it is increasingly often postulated in public debate to introduce a quota system into the organs of state administration, the more so as some European countries have already applied similar solutions.
\end{abstract}

